Benha Veterinary Medical Journal 41 (2021) 55-59

\begin{tabular}{|c|c|c|}
\hline & Benha Veterinary Medical Journal & 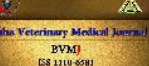 \\
\hline $\begin{array}{l}\text { Official Journal Issued by } \\
\text { Faculty of } \\
\text { Veterinary Medicine }\end{array}$ & Journal homepage: https://bvmj.journals.ekb.eg/ & $\begin{array}{c}=7 \\
\text { Since } 1990\end{array}$ \\
\hline
\end{tabular}

Original Paper

\title{
Molecular and serological diagnosis of Orf virus from sheep and goats in Minufiya governorate, Egypt
}

Esam A. Khalil1 ; Zeinab R. Aboezz2; Fouad S. El-mayet2; Ayman S. El-Habbaa2; Saad S. A. Sharawi1.

${ }^{I}$ Directorate of Veterinary Medicine, Shebin El-Kom, Minufiya, Egypt.

${ }^{2}$ Virology Department, Faculty of Veterinary Medicine, Benha University, Moshtohor 13736, Kaliobyia, Egypt.

ARTICLE INFO

Keywords

Orf virus

PCR

VLTF-1 gene

Received 17/07/2021

Accepted 25/07/2021

Available On-Line

01/10/2021

\begin{abstract}
Orf virus infecting sheep and goats belongs to genus Parapoxvirus, subfamily Chordopoxvirinae, family Poxviridae. It causes contagious pustular dermatitis in sheep and goats worldwide, including Egypt. This work aimed for molecular and serological diagnosis of Orf virus in infected sheep and goats during summer season 2020. Ten samples of skin lesions from suspected sheep and goats from different areas of Minufiya governorate including Queisna, Tala, and Ashmoon were subjected to direct detection using PCR primers targeting ORF 045 gene which encodes the late transcription factor (VLTF-1). Positive samples on PCR detection were isolated on Specific Pathogen Free- Embryonated Chicken Eggs (SPF-ECEs) then viral antigen was detected using indirect-fluorescent antibody technique (IFAT) and molecular detection of viral DNA using PCR. Positive results were shown in 7 samples (5/7 of sheep samples and 2/3 of goat samples) using PCR. Virus isolation from positive samples on SPF-ECE that gave positive results by the $3^{\text {rd }}$ passage in 5 of 7 samples ( 3 sheep isolates and two goat isolates). Signs of inoculated viral samples on CAM of SPF-ECEs showed thickening, edema, and hemorrhage of the membrane. These isolates showed positive results upon identification using IFAT and PCR. It was concluded that Orf virus was circulating among sheep and goats in Minufiya governorate Egypt, during summer 2020.
\end{abstract}

\section{INTRODUCTION}

Orf virus of sheep and goats is the prototype of the Parapoxvirus genus; belong to the sub-family Chordopoxvirinae of the Poxviridae and it primarily causes Contagious Pustular Dermatitis in goats, sheep, and other ruminants worldwide (Mercer and Haig, 1999; Lojkic et al., 2010; Karki et al., 2019). It is characterized by proliferative lesions in the skin developed as maculopapular then vesicular pustules on the skin around the lips, mouth muzzle, nostrils, teats, and oral mucosa in sheep and goats. The economic loss of the disease is due to unthriftiness and varying degrees of pain in lambs 3-6 months of age and severely affected adult animals (Radostitis et al., 2008; Kumar et al., 2015). Repeated infection with less severe pathological and shorter time for recovery occur in sheep (McKeever et al., 1988).High mortality rates occur in kids that may reach 93\% (Mazur and Machado 1989) because lesions in lips and udders prevent infected animals from suckling and grazing, resulting in rapid emaciation followed by death (Darbyshire, 1961; Mazur and Machado, 1989). Occupational infection in human is characterized by large, painful nodules in the hands and less frequently in the face (Haddock et al., 2017; Demiraslan et al., 2017).

The disease is endemic distributed worldwide (Zhang et al., 2015; Karki et al., 2019). In Egypt Orf virus infection occur among sheep and goats populations in multiple outbreaks of variable severity (Said et al., 2013; Ali et al., 2013).
The viral genome has a linear double-stranded DNA genome (134-139 kbp) with high G.C. content (63-64 \%) in comparison with other poxviruses (Moss, 2001; Delhon et al., 2004). It contains 132 putative genes most of which are located in the central part of the genome (Mercer et al., 2006). Like other poxviruses, Orf virus genome contains a large central coding region bounded by two identical inverted terminal repeat (ITR) regions (Venkatesan et al., 2020). The Orf virus genome contains ORFs of at least 60 codons with conserved 130 genes. The central genomic core region (ORFs 009 to 111) contains homologues of conserved poxvirus genes involved in basic replicative mechanisms and structure and morphogenesis of intracellular mature and extracellular enveloped virions (EEV) (Moss, 2001).

The laboratory diagnosis of Orf virus is based on virus isolation on the embryonated chicken egg then identification using electron microscopy (Said et al., 2013), agar gel immune-diffusion (AGIDT) test (Zeedan et al., 2015), immunofluorescence assay (IFA) (Ali et al., 2013) and Enzyme-Linked Immunosorbent Assay (ELISA) (Bora et al., 2016).

Polymerase chain reaction (PCR) revealed a reliable laboratory diagnostic technique for diagnosing Orf virus infections (Hosamani et al., 2007, Mahmoud et al., 2010; Karki et al., 2019). Molecular analysis of Orf virus has been performed and these studies were generally based on the sequencing of the major envelope gene (B2L) but also on the analysis of the viral interferon resistance (VIR) and 
late transcription factor VTLF-1 (O45) genes (Kottaridi et al., 2006; Galante et al., 2019; Coradduzza et al., 2021).This work aimed for diagnosis of Orf virus in clinically suspected sheep and goats at different areas of Minufiya governorate.

\section{MATERIAL AND METHODS}

\subsection{Virus strain and antiserum}

An ECE adapted Orf virus at a titer of $5 \log _{10} \mathrm{EID}_{50} / \mathrm{ml}$, obtained from the virology department, Animal Health Research Institute, Dokki, Egypt. It was used as a positive control for both serological tests and PCR.

Rabbit anti-serum against Orf virus was obtained from the virology department, Animal Health Research Institute, Dokki, Egypt. It was used for indirect Fluorescent Antibody Technique (IFAT).

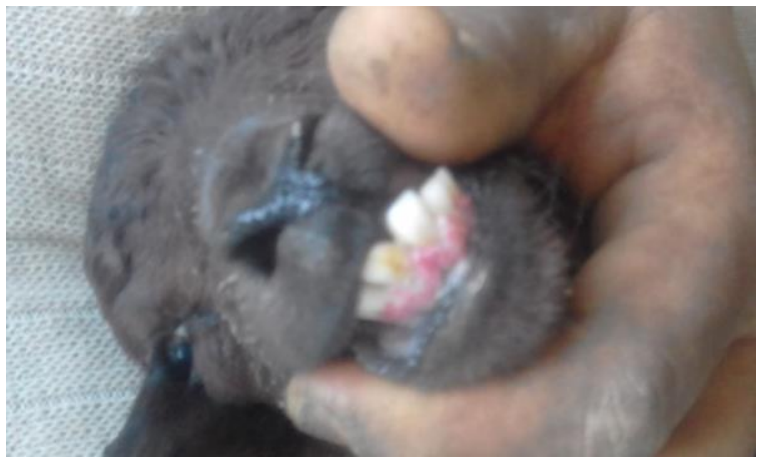

Photo No (1): Nodular and pustular lesions on the lower gum of Orf suspected lamb

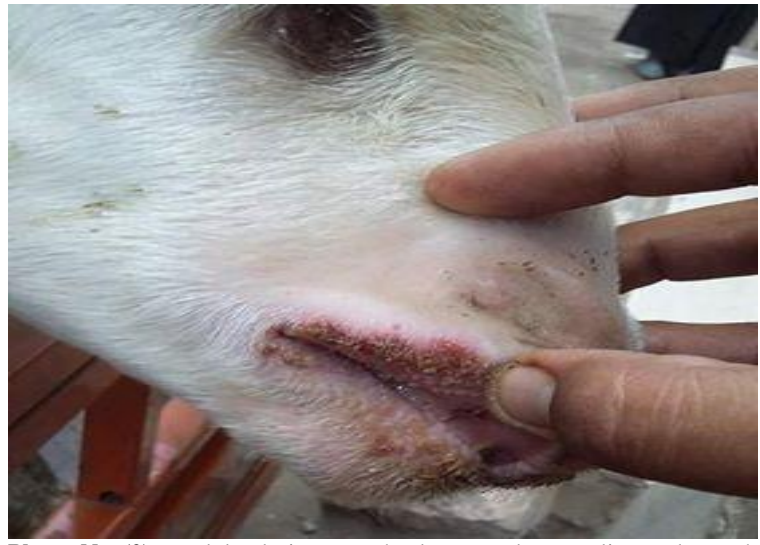

Photo No (2): Nodular lesions on the lower and upper lips and mouth commissures of Orf suspected goat

\subsection{Samples}

Ten scabs samples were collected from grassing sheep and goats (7 from sheep and three from goats) in different localities in Minufiya governorate including Queisna, Tala and Ashmoon. Animals were suspected of Orf virus infection due to skin lesions in the form of scabs and nodules on lips especially at its commissures and gums (photos 1 and 2). Samples were collected on $50 \%$ glycerol buffered saline then kept at $4^{\circ} \mathrm{C}$ until samples prepared. A $10 \%$ suspension of scab in phosphate- buffered saline containing $5 \%$ of stock antibiotic solution were homogenized with sterile sand in mortars, frozen and thawed for three successive times then centrifuged at 3,000 $\times \mathrm{g}$ for 10 minutes and supernatants stored at $-20^{\circ} \mathrm{C}$ until used for virus for isolation and PCR detection (OIE, 2008).
2.3. Specific pathogen free-Emberyonated Chicken Eggs (SPF-ECES)

SPF-ECE were obtained from Koom Osheem farm, ElFayum governorate, incubated at egg incubator for 10 days old and used for Orf virus isolation on chorio-allantoic membrane (CAM) (Tantawi et al., 1979).

\subsection{Indirect Fluorescent Assay (IFAT)}

It was used to detect Orf virus antigen in impression smears from CAM of SPF-ECE inoculated with the virus isolates. The technique was performed according to Soliman et al., (1996) using reference Orf antiserum and anti-sheep and anti-goat $\operatorname{IgG}$ conjugated with fluorescein isothiocynate (Sigma, USA).

\subsection{Genomic DNA extraction}

Viral genomic DNA was extracted from the prepared samples of scabs and the inoculated ECE with pock lesions by using QIAamp DNA Mini kit (QIAGEN, USA;Cat. No. 51306) according to the manufacturer's instructions, and then the extracted DNA was eluted with $100 \mu$ l elution buffer and stored at $-20{ }^{\circ} \mathrm{C}$ until used for PCR

\subsection{Polymerase chain reaction $(P C R)$}

The primers used in our study were VLTF- 1 gene-F ( $5^{\prime}-$ CCT ACT TCT CGG AGT TCA GC-3') and VLTF-1 gene-R (5'-GCA GCA CTT CTC CTC GTA G-3') according to Kottaridi et al., (2006). PCR was performed in a $50-\mu \mathrm{L}$ reaction mixture that contained $25 \mu \mathrm{L} 10 \mathrm{X}$ buffer I, $500 \mathrm{mM}$ of each deoxyribonucleotide triphosphate, 0.4 $\mathrm{mM}$ of each oligonucleotide primer, $200 \mathrm{ng}$ of each DNA sample, and 1.0 U LA Taq DNA polymerase with 10X buffer (Takara). PCR amplification proceeded with an initial denaturation step of $95^{\circ} \mathrm{C}$ for 5 min followed by 40 cycles at $95^{\circ} \mathrm{C}$ for $10 \mathrm{~s}, 47^{\circ} \mathrm{C}$ for $10 \mathrm{~s}, 72^{\circ} \mathrm{C}$ for $15 \mathrm{~s}$, and a final extension of $72^{\circ} \mathrm{C}$ for $10 \mathrm{~min}$. The primer sequences targeting the VTLF-1 gene supposed to amplify 392 bp fragments were selected for amplification of DNA. PCR amplified products were analyzed on $1.5 \%$ agarose gel, stained with Gel Red ${ }^{\mathrm{TM}}$ Nucleic Acid Gel Stain, 10,000X in water (BIOTREND) and then visualized under U.V. light. A TrackIt ${ }^{\mathrm{TM}} 100 \mathrm{bp}$ DNA ladder (Invitrogen) was used as a DNA base pair marker.

\section{RESULTS}

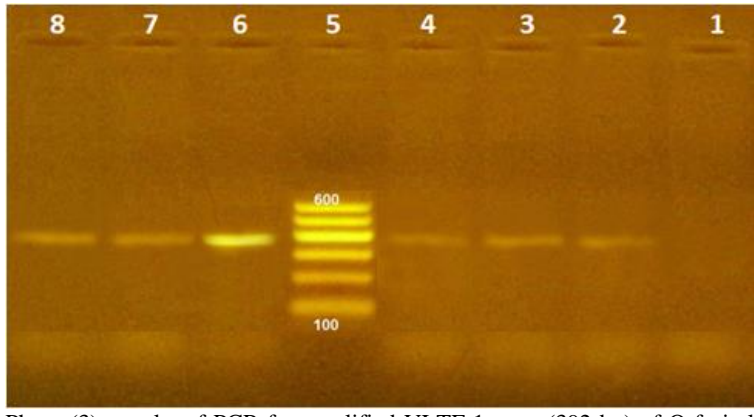

Photo (3): results of PCR for amplified VLTF-1 gene (392 bp) of Orf vira nucleic acids from suspected samples. Lane (1) negative PCR results. Lane (2) positive PCR products from sheep sample (tissue sample). Lane (3) positive PCR products from sheep sample (tissue sample). Lane (4) positive PCR products from sheep sample (tissue sample). Lane (5) 100bp marker. Lane (6) positive PCR products from Orf virus reference strain. Lane (7) positive PCR products from goat sample (tissue sample). Lane (8) positive PCR products from goat sample (tissue sample)

3.1. Detection of Orf virus in collected samples by PCR: Viral genomic DNA was extracted from the collected samples of affected animals; all samples were screened 
with PCR. The expected size of PCR product as $392 \mathrm{bp}$ of VTLF-1 gene of the Orf virus was successfully detected in 7 out of 10 samples (70\%), (5/7 of sheep samples and 2/3 goat samples) (Table 3 and Photo no.3).

Table (1): isolation of suspected Orf virus from sheep and goats samples in SPF-ECE as detected by thickening, oedema and hemorrhage of CAM

\begin{tabular}{|c|c|c|c|c|c|}
\hline \multirow[t]{2}{*}{ Species } & \multirow{2}{*}{\multicolumn{2}{|c|}{$\begin{array}{c}\text { Total number of } \\
\text { samples }\end{array}$}} & \multicolumn{3}{|c|}{ Number of positive samples } \\
\hline & & & $\begin{array}{c}1^{\text {st }} \\
\text { passage }\end{array}$ & $\begin{array}{c}2^{\text {nd }} \\
\text { passage }\end{array}$ & $\begin{array}{c}3^{\text {rd }} \\
\text { passage }\end{array}$ \\
\hline Sheep & \multicolumn{2}{|c|}{7} & 2 & 3 & 3 \\
\hline Goats & \multicolumn{2}{|c|}{ 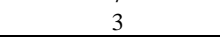 } & 1 & 2 & 2 \\
\hline Total & \multicolumn{2}{|c|}{10} & 3 & 5 & 5 \\
\hline \multicolumn{6}{|c|}{ Table (2): Detection of Orf virus using PCR and IFAT } \\
\hline \multirow[b]{2}{*}{ Species } & \multicolumn{3}{|c|}{ Number of samples } & \multicolumn{2}{|c|}{ Number of isolates } \\
\hline & Examined & $\begin{array}{c}\text { Positive } \\
\text { PCR }\end{array}$ & $\begin{array}{l}\text { Positive } \\
\text { isolation }\end{array}$ & $\begin{array}{l}\text { Positive } \\
\text { IFAT }\end{array}$ & $\begin{array}{l}\text { Positive } \\
\text { PCR }\end{array}$ \\
\hline Sheep & 7 & 5 & 3 & 3 & 3 \\
\hline Goats & 3 & 2 & 2 & 2 & 2 \\
\hline Total & 10 & 7 & 5 & 5 & 5 \\
\hline
\end{tabular}

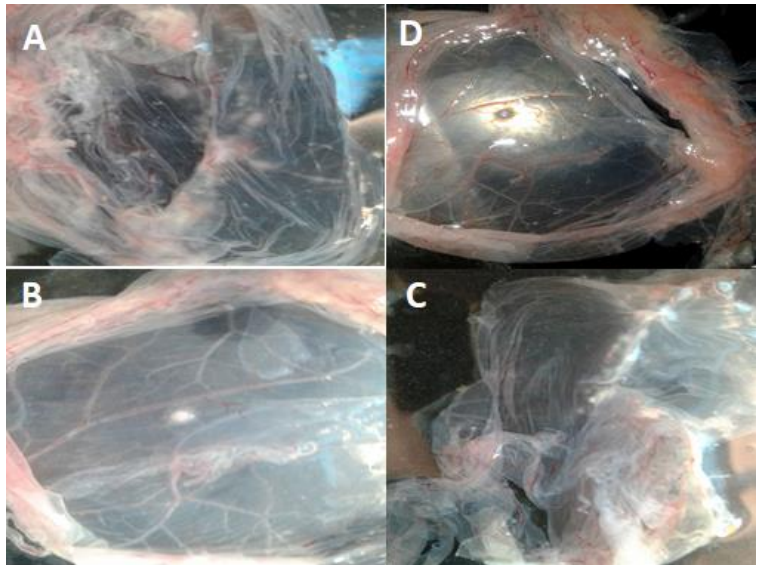

Photo No (4). Signs of inoculated viral samples on CAM of SPF-ECE showed thickening, edema and hemorrhage of the membrane (plates A, B \& C), Control non-infected membrane (D)

\subsection{Orf isolation on CAM:}

Inoculation of the prepared samples from skin lesions on CAM of SPF-ECE were positive in $5 / 10$ samples $(50 \%)$, $3 / 7$ samples from sheep $(42.85 \%)$ and $2 / 3$ samples from goats $(66.66 \%)$ by the $3^{\text {rd }}$ passage (Tables 1 and 2$)$. The signs on inoculated CAM are thickening in the CAM at 6 7 days post-inoculation (Photo no. 4).

\subsection{Indirect Fluorescent Assay (IFAT):}

Detection of Orf virus proteins in impression smears from the CAM of ECEs with suspected isolates using reference Orf antiserum and anti-sheep and anti-goat IgG conjugates revealed that isolates on CAM of SPF-ECE were positive for the presence of viral antigen by IFT in isolated sheep and goat samples. The positive result of IFAT appeared as a specific yellow-green emission from the rounded cells lining the CAM in the impression smears examined under the fluorescent microscope in comparison to the result of the negative control (Photos $5 \& 6$ ).

\subsection{Detection of Orf virus isolates by PCR:}

Viral genomic DNA was extracted from the inoculated chorioallantoic membranes showing thickening and then screened with PCR. The expected size of PCR product as 392 bp of the (045) gene of Orf virus was successfully detected in all samples after isolation (3 sheep samples and 2 goat samples), (Table 2). The amplification and running of characteristic $392 \mathrm{bp}$ (base pair) fragments of Orf viral DNA as stronger running bands were shown in photo (7).

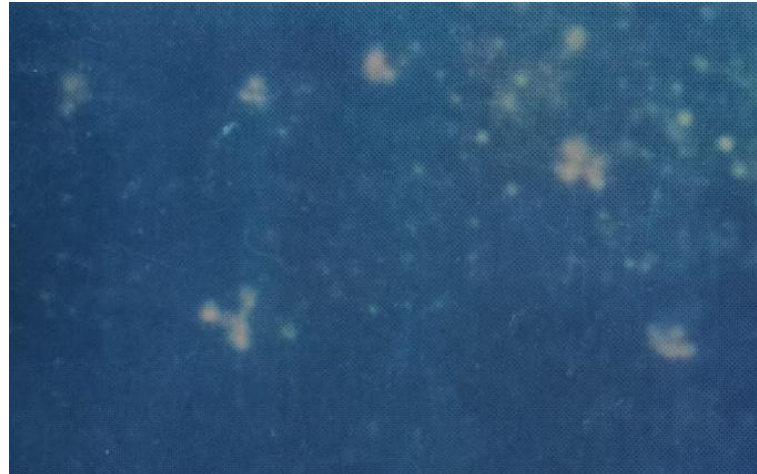

Photo (5): Specific yellow green fluorescence of rounded cells infiltrated between and under epithelial cells lining CAM impression smears

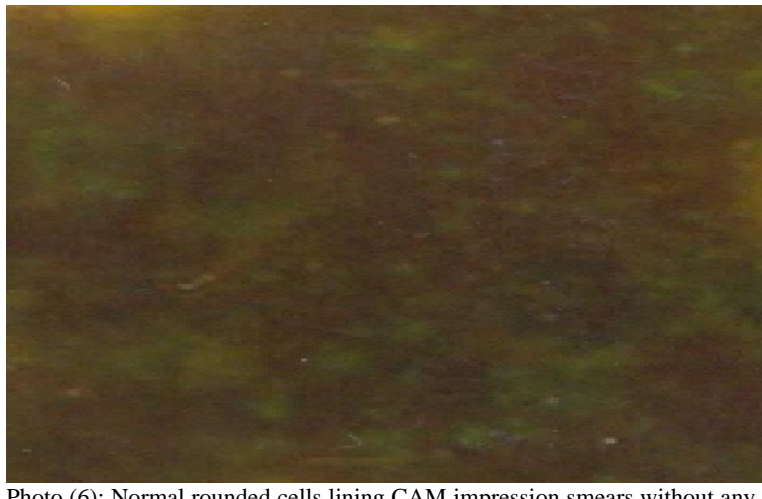

Photo (6): Normal rounded cells lining CAM impression smears without any emission

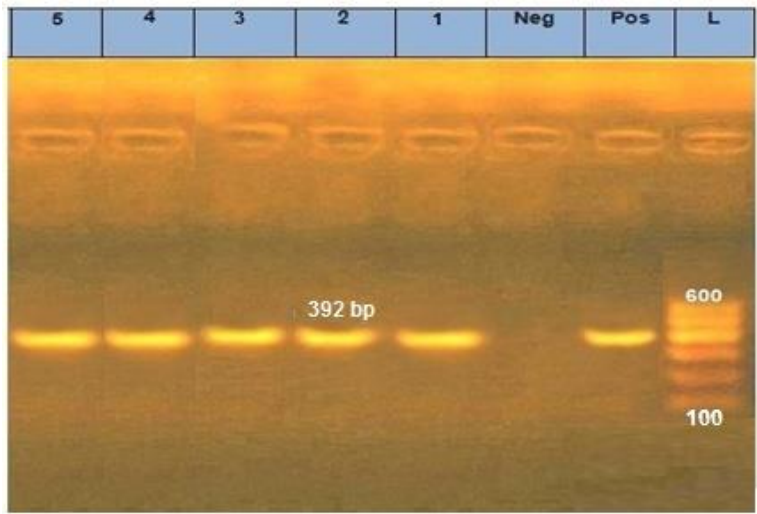

Photo (7): results of PCR for amplified VLTF-1 gene of Orf viral nucleic acids for isolates harvested from CAM of SPF-ECE.The amplification and running of characteristic $392 \mathrm{bp}$ (base pair) fragments of Orf viral DNA were shown. Lane (L):100bp marker. Lane (Pos): positive PCR products from Orf virus reference strain. Lane (Neg): negative control. Lane (1, 2 \& 3) positive PCR products for sheep isolate. Lane $(4 \& 5)$ positive PCR products for goat.

\section{DISCUSSION}

Orf virus is an epitheliotropic DNA parapoxvirus with a worldwide distribution that induces acute pustular lesions in the skin of sheep, goats and humans (Haig and Mercer, 1998). Orf virus belongs to genus Parapoxvirus, family Poxviridae (Robinson and Balassu, 1981). The disease is characterized by papules, pustules and scabs covering ulceration at the oral mucocutaneous junction, oral commissures and spread to muzzle, oral cavity (Radostitis et al., 2008).

This work aimed to use PCR based on VTLF-1 gene primersfor diagnosis of Orf virus in sheep and got samples before and after isolation on SPF-ECEs that was confirmed using IFAT. 
Orf virus genome consists of linear double-stranded DNA that measures $138 \mathrm{kbp}$ in length and contains 132 putative genes most of them are located in the central part of the genome, well conserved and homologous to other poxvirus genes that encode products involved in replication, structure and morphogenesis of the virus. Other genes are located in the terminal regions and encode genes with no homology with other poxvirus sequences, whose products are involved in the determination of virus virulence, host range and evasion of the immune response (Mercer et al., 2006).

Viral genomic DNA extracted from prepared samples collected from clinically suspected animals were subjected to PCR using specific primers for the VTLF-1 gene of Orf virus (Kottaridi et al., 2006; Galante et al., 2019; Coradduzza et al., 2021). The expected size of PCR product as $392 \mathrm{bp}$ of the VTLF-1gene of Orf virus was successfully detected in 7 out of 10 samples (70\%), (5/7 of sheep samples and $2 / 3$ goat samples) before isolation (Table 3 and Photo no. 3).

The results proved PCR sensitivity in the detection of Orf virus in skin samples from suspected animals (Magnana et al., 2000; Kottaridi et al., 2006; Mahmoud et al., 2010; Babu et al. 2018).

Virus isolation from prepared samples on CAM of ECE showed that $3 / 10(30 \%)$ from sheep samples and 2/10 $(20.00 \%)$ from goats samples were positive by the $3^{\text {rd }}$ passage with the inoculated CAM showed thickening at 6 7 days post-inoculation (Tables 1 and 2). These results agreed with (Mangana et al., 1999, 2000; Ali et al., 2013; Babu et al. 2018) who preferred isolation of the virus on ECEs for their ease of use, simplicity of procedures and equipment required and rapidity with the result appeared within short period.

Using indirect-FAT for examination of inoculated CAM of ECE showed positive results for the presence of Orf virus antigen in 3 isolates from sheep samples and 2 isolates from goat samples (Table 2 and Fig. 4 and 5). This result agreed with the results showed that the indirect FAT is a rapid confirmatory assay for the detection of Orf virus inoculated on CAM of ECE that could be used routinely in diagnostic laboratories (Mazur and Machado, 1990; Mangana et al., 2000; Ali et al., 2013).

Although virus isolation followed by virus identification using FAT is considered a gold standard for diagnosis of Orf virus, they are time-consuming and laborious (Mazur and Machado, 1990; Mangana et al., 2000; Ali et al., 2013). So, PCR is considered a sensitive, specific, and fast tool for the detection of the Orf virus that is preferred over the conventional serological techniques. The inoculated chorioallantoic membranes showing thickening are screened with PCR based on the VTLF-1 gene of Orf virus that successfully detected Orf virus in all samples positive for isolation and FAT ( 3 sheep isolates and 2 goat isolates), (Table 2). The amplification and running of characteristic 392 bp (base pair) fragments of Orf viral DNA as stronger running bands were shown in photo (7). The results proved superior PCR sensitivity than that of egg inoculation method then detection with indirect FAT (Magnana et al., 2000, Kottaridi et al., 2006; Mahmoud et al., 2010; Babu et al. 2018)

\section{CONCLUSION}

Orf virus was emerging in both sheep and goats from Minufiya governorate Egypt during summer season 2020. Sensitive, reliable, and specific techniques were used for diagnosis of Orf virus including PCR and IFAT.

\section{CONFLICT OF INTEREST}

The authors declare that they have no conflicts of interest for current data

\section{REFERENCES}

1. Ali, M.H.; Ahmed, M.H.; Tamam, S.M.; Arafa, A.; Saad, A.A.; Ali, W.F.; Madbouly, H.M. 2013. Molecular Characterization of Orf Virus Isolated from Sheep and Goats in Egypt. Global Veterinaria 11 (1): 98-106. DOI: 10.5829/idosi.gv.2013.11.1.74173

2. Babu, T.S.; Rathnamma, D.; Shrikrishna I.; Chandranaik, B.M.; Veeregowda, B.M.; Manjunath Reddy, G.B. 2018. Diagnosis of Orf virus infection in sheep and goats by virus isolation, polymerase chain reaction and sequencing. Journal of Experimental Biology and Agricultural Sciences; Volume 6(1) page $176-187$

3. Bora, M.; Bora, D.P.; Barman, N.N.; Borah, B.; Das, S. 2016 Seroprevalence of contagious ecthyma in goats of Assam: An analysis by indirect enzyme-linked immunosorbent assay. Vet World. $2016 \quad$ Sep; $\quad 9(9)$ : $1028-1033$. doi: 10.14202/vetworld.2016.1028-1033

4. Coradduzza, E.; Sanna, D.; Rocchigiani, A.M.; Pintus, D.; Scarpa, F.; Scivoli, R.; Bechere, R.; Dettori, M.A.; Montesu, M.A.; Marras, V.; et al. 2021. Molecular Insights into the Genetic Variability of ORF Virus in a Mediterranean Region (Sardinia, Italy). Life, $11, \quad 416$ https://doi.org/10.3390/life11050416

5. Darbyshire, J. H. 1961. A fatal, ulcerative mucosal condition of sheep associated with the virus of contagious pustular dermatitis. Br. Vet. J. 117: 97-105.

6. Delhon, G.; Tulman, E. R.; Afonso, C. L.; Lu, Z.; de la Concha-Bermejillo, A.; Lehmkuhl, H. D.; Piccone, M. E.; Kutish, G. F. and Rock, D. L. 2004. Genomes of the ParapoxvirusesOrf Virus and Bovine Papular Stomatitis Virus. Journal of Virology, Jan. 2004, Vol. 78, No. 1 p. 168-177.

7. Demiraslan, H.;Dinc, G.; Doganay, M. 2017. An overview of Orf virus infection inhumans and animals. Recent Pat. Antiinfect. Drug. Discov. 12, 21-30.

8. DOI: $10.2174 / 1574891 \times 1266617060208030$

9. Galante, D.; Cafiero, M.A.; Raele, D.A.; Pugliese, N.; Padalino, I.; Cavaliere, N.; Buonavoglia, C. 2019.

Identification and characterization of Orf viruses isolated from sheep and goats in Southern Italy. Veterinaria Italiana 2019, 55 (4), 347-353. doi: 10.12834/VetIt.1025.5477.2.

10. Haddock, E. S.; Cheng, C. E.; Bradley, J. S.; Hsu, C.H.; Zhao, H.; Davidson, W.B.; Barrio, V.R. 2017. Extensive orf infection in a toddler with associated id reaction. Pediatr. Dermatol. 34, e337-340. DOI: 10.1111/pde.13259

11. Haig, D.M. and Mercer, A.A. 1998. Orf "Review Article". Veterinary Research, 29: 311-326.

12. Hosamani, M., Yadav, S., Kallesh, D.J., Mondal, B., Bhanuprakash, V. and Singh, R.K. (2007): Isolation and Characterization of an Indian Orf V irus from Goats.Zoonoses Public Health, 54:204-208.

13. Karki, M.; Venkatesan, G.; Kumar, A.; Kumar, S.; Bora, D.P. 2019. Contagious ecthyma of sheep and goats: a comprehensive review on epidemiology,immunity, diagnostics and control measures. Vet. arhiv 89, 393-423.

14. Kottaridi, C., Nomikou, K., Lelli, R., Markoulatos, P., Mangana, O. (2006): Laboratory diagnosis of contagious ecthyma: comparison of different PCR protocols with virus isolation in cell culture. J. Virol. Meth. 134, 119-124.

15. Kumar, R.; Trivedi, R.N.; Bhatt, P.; Khan, S.H.; Khurana, S.K.; Tiwari, R.; Karthik, K.; Malik, Y.S.; Dhama, K.; Chandra, R. 2015. Contagious pustular dermatitis (orf disease) - epidemiology, diagnosis, control and public health concerns. Adv. Anim. Vet. Sci. 3(12): 649-676..

16. Lojkic, I.; Cac, Z.; Beck, A.; Bedekovic, T.; Cvetnic, Z.; Sostaric, B. 2010.Phylogenetic analysis of Croatian orf viruses isolated from sheep and goats. Virology Journal 2010, 7:314.

17. Magnana-Vougiouka, O., Markoulatos, P., Koptopoulos, G., Nomikou, K., Bakandritsos, N. and Papadopoulos, O. 1999. 
Sheep poxvirus identification by PCR in cell cultures. J. Virol. Meth. 77, 75-79.

18. Magnana-Vougiouka, O., Markoulatos, P., Koptopoulos, G., Nomikou, K., Bakandritsos, N. and Papadopoulos, O. 2000. Sheep poxvirus identification from clinical specimens by PCR, cell culture, immunofluorescence and agar gel immunoprecipitation assay. Mol. Cell. Probes 14, 305-310.

19. Mahmoud, M., Abdelrahman, K. and Soliman, H. (2010): Molecular and virological studies on contagious pustular dermatitis isolates from Egyptian sheep and goats. Res. Vet. Sci.; 89(2):290-294.

20. Mazur, C.; Machado, R.D. 1989. Detection of contagious pustular dermatitis virus of goats in a severe outbreak. Vet. Rec. 125:419-420.

21. McKeever, D. J.; McEwan, P. E.; Jenkinson, D. M.; Hutchinson, G. and Reid, H. W. 1988. Studies of the pathogenesis of orf virus infection in sheep. J. Comp. Pathol. 99:317-328.

22. Mercer, A.A.; Haig. D.M. 1999.Parapoxviruses, p. 1140 1146. In A. Granoff and R. G. Webster (ed.), The encyclopedia of virology, 2nd ed. Academic Press, New York, N.Y.

23. Mercer, A.A.; Uedaa, N.; Friederichs, S.; Hofmann, K.; Fraser, K.M.; Bateman, T.; Fleming, S.B. 2006. Comparative analysis of genome sequences of three isolates of Orf virus reveals unexpected sequence variation. Virus $R$ esearch 116 :146-158

24. Moss, B. 2001. Poxviridae: the viruses and their replication, p. 2849-2883. In B. N. Fields, D. M. Knipe, P. M. Howley, R. M. Chanock, J. L. Melnick, T. P. Monathy, B. Roizman, and S. E. Straus (ed.), Fields virology, 4th ed. Lippincott, Williams and Wilkins, Philadelphia, Pa.
25. OIE Manual of Diagnostic (2008): Chapter 2.7.14 Sheep pox and goat pox Terrestrial Animals under the heading "Diagnostic Techniques".

26. Radostits, O.M., Gay, C.C., Hinchcliff, K. W. and Constable, P.D. 2008. Veterinary medicine, A Textbook of The Diseases of Cattle, Horses, Sheep, Pigs and Goats. $10^{\text {th }}$ Edn., W.B. Sounders, London, New York, Oxford.

27. Robinson, A.J.; Balassu, T.C. 1981. Contagious pustular dermatitis (orf). Vet Bull, 51:771-82.

28. Said, A.A.; Mohamed, S.I.; AbdElhamid, N.K.; Hosny, W.A.; Baheeg, E.M. 2013. Trials for Isolation of Contagious Pustular Dermatitis Virus (CPDV) from Sheep in Ismailia Governorate. Res. Zool. 3(1): 10-14.

29. Soliman, S.M.; Zaghloul, W.A.; Fayed, M.A.A.; Taha, M.M. 1996. Studies on sheep pox and goat pox viruses from naturally infected animals. Assiut Vet. Med. J. 35(70), 29-38.

30. Tantawi, H.H.; Fayed, A.A.;Shalaby, M.A.;Skalinsky, E.I 1979. Isolation, cultivation and characterization of pox viruses from Egyptian water buffaloes. Journal of the Egyptian Veterinary Medical Association 37: 15-23.

31. Venkatesan, G.; Kumar, A.; Bhanuprakash, V.; Balamurugan, V.; Singh, R.K. 2020. Capripoxvirus and Orf Virus. Y. S Malik et al. (eds.), Animal-Origin Viral Zoonoses, Livestock Diseases and Management, (c) Springer Nature Singapore Pte Ltd. 2020. https://doi.org/10.1007/978-981-15-2651-0_9

32. Zhang, K.; Xiao, Y.; Yu, M.; Liu, J.; Wang, Q.; Tao, P.; Liu, S.; Ning, Z. 2015. Phylogenetic analysis of three orf virus strains isolated from different districts in Shandong Province, East China. J Vet Med Sci. [Epub ahead of print] PMID: 26311786. http://dx.doi.org/10.1292/jvms.15-0368 